\title{
INTRODUCTION-DIASPORAS AND IDENTITY: TOURISM, BEING, AND BECOMING
}

\author{
NAZIA ALI* AND MILKA IVANOVA $\dagger$
}

\author{
*London College of Hospitality and Tourism, University of West London, London, UK \\ $\dagger$ Department of Business Systems and Operations, University of Bedfordshire, Luton, UK
}

This special issue of Tourism, Culture \& Communication on "Diasporas and Identity: Tourism, Being, and Becoming" advances theoretical, conceptual, and empirical research on diasporic identities and attachments in the context of tourism. The call for articles was inspired by our philosophical, theoretical, and research interests in diasporas in and beyond tourism studies, in particular cultural, postcolonial, and intercommunication studies. The collection of articles in this special issue provide original and innovative international tourism research studies that are embedded with interdisciplinary and transdisciplinary theoretical, conceptual, and methodological thought in the study of being and becoming. The emphasis is on critically interpreting the influence of diasporic identities, which are communicated through tourism-related travels and activities. This special issue inspects diasporic-orientated journeys, physical and imaginary, of Celts living in Australia, Indians and Iranians in New Zealand, Poles resident in the UK, and Ukrainian settlers in the US. The critical interpretations bring to the forefront the reimaginative nature of diaspora travel-related journeys and happenings, which as a force for being and becoming creates messed up worlds for diasporas as their identities are transported to and from the host and homeland in a variety of communicative conduits such as culture, events, narrative, performances, places, rituals, symbols, and traditions.

The seven articles in this special issue confirm and challenge the cultural and communicative value of diaspora tourism journeys, and appreciate the sliding (as opposed to the solidness) hybrid positions diasporas encounter in "home" and "host" countries. The first article by Keith Hollinshead is a critical insight of the "diversiform character" of the "imagined" diasporic network in tourism studies. Hollinshead applies the work of the cultural theorist Paul Gilory to comprehend the hybrid beings and becomings of diasporas in terms of the entanglement encounters or "mixed up" positions in between "old imprints" and "new inscriptions" of identifications. The work of Hollinshead paves the way for the following six articles, which take forward issues of the "diversiform character" of diasporas in tourism research such as "restless populations," "third-space peoples," "difficult psychological spaces," and "negotiated selfhood."

Accordingly and thereafter, the second article by Milka Ivanova and Keith Hollinshead is the companion manuscript to the first article. Ivanova and Hollinshead's rich and critical inspections lay the transdisciplinary underpinnings to creatively and imaginatively examine "diasporas disentangled." Central to Ivanova and Hollinshead is the power 
of transdisciplinary trajectories, which lend themselves to open, critical, and imaginative research in diaspora (tourism) studies. The article responds to the call for improved research into complexities of diasporic affiliations. This article of "diasporas disentangled" captures the essence of the other articles in this special issue, which are ontologically alert to transdisciplinary lines of inquiry, and are epistemologically and methodologically committed to unravel the complex beings and becomings of diasporas in tourism studies.

The third article by Mitra Etemaddar, Hazel Tucker, and Tara Duncan discusses domestic diaspora tourism activities of the Iranian diaspora living in Dunedin, New Zealand. The authors challenge current dominant understandings of diaspora tourism, which are confined and restricted to return visits to cultural, ethnic, or religious homelands. Diaspora tourism movements taking place in the host country-New Zealand-as the Iranian diaspora spend time with one another during their travels re-create, in physical spaces, imaginative links with the homeland, Iran. This reinforces diasporic ties and attachments to the ancestral homeland from afar, and thus strengthens networks and friendships with fellow diasporas in New Zealand. By being together the Iranian diaspora explore their "new" homeland together and in doing so work together to navigate through the processes of becoming in a new place.

In the fourth article Joanna Alder considers the role of travel and food as signifiers of diasporic identity among Poles in Derby, UK. Diaspora tourism journeys to the ancestral homeland-Polandoften present opportunities to engage with food and reaffirm expressions of Polish identity. Alder recognizes the importance of tourism and food as traveling materials, and their interrelationship in connecting the Polish diaspora across three postWorld War II generations, physically and imaginatively, to their ancestral homeland. The rich interpretive qualitative accounts focus on those who did and did not visit the homeland, and how travel and food were symbolic in mobilizing the diaspora. Alder's work continues the discursive points raised in Etemaddar, Tucker, and Duncan's article in view of the imaginative ties with the ancestral homeland as fellow diaspora people revive their bonds with "old" homes from afar.
The next article by Alison Booth examines the contested and conflictual nature of the cultural and religious festival-Diwali. Booth asks: "Whose Diwali is it?" as the event in Auckland, New Zealand has been subjected to commercialized alterities by stakeholders or a case of "festivalization," and consequently affected the cultural representation and identity of the Indian diaspora. The soft power of the Diwali festivities has been shadowed with the hard power of commodified audiencing of the event, thus producing "alien" representations that are unrecognizable to the Indian diaspora and that cannot be nostalgically aligned to the "old" or "authentic" Diwali event situated in the homelandIndia. In order to map the changing inscriptions of Indianness associated with the Diwali event Booth presents her ethnographic analysis using "producer network maps."

In the sixth research article Joanne Mackellar provides a quantitative and qualitative analysis of the influence of Celtic diaspora in reimagining homeland experiences in migrant settlements. The Australian Celtic Festival in Glen Innes, Australia is the focus of the article to illustrate how festival activities facilitate links between the communication of culture within tourism spaces. These tourism spaces and places are elected centers, which maintain rituals, symbols, and ceremonies as markers of identity and elements of the homeland. Mackellar emphasizes the multisensory experiences, associated with event design, central to domestic diasporic event tourism activities. The event is a tool to mobilize the being and becoming of the Celtic diaspora in the migrant settlement as it introduces host communities to their culture and connects with others in the diaspora. Mackellar's emphasis is on imaginative place making in hybrid spaces by third-space populations and offers an alternative interpretation to Booth's discussion on diasporic event tourism activities in host lands.

The final article by Svitlana Iarmolenko and Deborah Kerstetter investigates diasporic identity, adjustment issues, and propensity for transnational travel of the fourth-wave Ukrainian immigrants in New York (USA). Fourth-wave migrants are the most recent arrivals who are representative of transnational immigrants with ties to host and homeland. Iarmolenko and Kerstetter draw attention to the disconnective element of diaspora 
tourism, which through physical and virtual travels to the ancestral homeland-Ukraine-impacts on positioning of Ukrainian diasporic identities. In particular, there are tensions between nationalistic third-wave migrants and nationalistically disillusioned fourth-wave migrants. Consequently, this affects the process of adjustment, settlement, and transnational relations of fourth-wave Ukrainians in their "home" and "host" nations. In their work, Iarmolenko and Kerstetter challenge the homogeneous nature of diasporas and their supposedly common pre- and postmigration experiences associated with transnational diaspora travel.

The articles in this special issue are summarized in a final endnote. We would like to thank Professor Keith Hollinshead for his guidance and enthusiasm for this special issue as we conducted our guest editorial duties. Also, we are indebted to the coeditors of Tourism, Culture \& Communication-Professor Brian King and Dr. Wantanee Suntikul - for their support and assistance. This special issue would not have been possible without the dedication, hard work, timely responses, and patience of the contributors and their insightful and interesting research studies. Finally, we hope that the collection of articles in this special issue will encourage further contributions to the debate on diasporas and identities in view of tourism. Future studies should continue to challenge the dominant categorizations of diaspora-related travel (e.g., ethnic reunion journeys, homecoming tourism, diaspora tourism, return visits, visiting friends and/ or relatives) to draw attention to the (imaginative) complexities of diasporic communications and affiliations in and beyond tourism studies. 
Copyright of Tourism Culture \& Communication is the property of Cognizant Communication Corporation and its content may not be copied or emailed to multiple sites or posted to a listserv without the copyright holder's express written permission. However, users may print, download, or email articles for individual use. 